\title{
Tıp Fakültesi Öğrencilerinin Hekimlik Mesleğine Yönelik Tutumları: Preklinik ve Klinik Eğitim Dönemlerinin Karşılaştırılması
}

\section{Attitudes of Medical Students towards Medical Profession: Comparison of Pre-Clinical and Clinical Education Periods}

Funda Ifakat Tengiz ${ }^{1}$ (Orcid: 0000-0002-8491-9190)

Asya Banu Babaoğlu² (Orcid: 0000-0002-1259-1288)

Esra Meltem Koç3 (Orcid: 0000-0003-3620-1261)

Gülseren Pamuk ${ }^{4}$ (Orcid: 0000-0001-5556-9630)

'Dr. Öğr. Üyesi, İzmir Kâtip Çelebi Üniversitesi Tıp Fakültesi Tıp Eğitimi Anabilim Dalı

${ }^{2}$ Dr. Öğr. Üyesi, İzmir Kâtip Çelebi Üniversitesi Tıp Fakültesi Halk Sağlığı Anabilim Dalı

${ }^{3}$ Dr. Öğr. Üyesi, İzmir Kâtip Çelebi Üniversitesi Tıp Fakültesi, Aile Hekimliği Anabilim Dalı

${ }^{4}$ Dr. Öğr. Üyesi, İzmir Kâtip Çelebi Üniversitesi Tıp Fakültesi, Aile Hekimliği Anabilim Dalı

Sorumlu Yazar: Funda Tengiz

Anahtar Sözcükler: hekimlik mesleği, tutum, tutum ölçeği, tıp eğitimi, afiliasyon

Keywords: medical profession, attitude, attitude scales, medical education, affiliation

Gönderilme Tarihi

Submitted:09.09.2019

Kabul Tarihi

Accepted: 16.12.2019
ÖZET:

Amaç: Tutum, "yaşantı ve deneyimler sonucu oluşan, bireyin ilgili olduğu tüm nesne ve durumlara karşı davranışları üzerinde yönlendirici ya da dinamik bir etkiye sahip, ruhsal hazırlık durumu" olarak tanımlanır. Tutumun, bireylerin davranışlarını yönlendirici ve başarılarında etkili bir eleman olduğu belirtilmektedir. Tutumlar varsayılan değişkenlerdir ve doğrudan ölçülemezler. $\mathrm{Bu}$ nedenle, tutumları değerlendirmek için bireylere düşüncelerini, duygularını ve olaylara tepkileri sorulur. Yeni bilgi ve deneyimler tutumların değişmesine sebep olur. Öğrenci davranışlarının olumlu yönde değişmesi, başarısının arttırılması için tutumlarının ölçülüp gerekli değişimlerin yapılması önemlidir. $\mathrm{Bu}$ çalışmanın amacı, tıp fakültesi öğrencilerinin hekimlik mesleğine yönelik tutumlarını ve tutumlarda preklinik ile klinik dönem arasında fark olup olmadığını belirlenmektir.

Künye: Tengiz F, Babaoğlu A, Koç E, Pamuk G. Tip Fakültesi Öğrencilerinin Hekimlik Mesleğine Yönelik Tutumları: Preklinik ve Klinik Eğitim Dönemlerinin Karşılaştırılması. 2020;19(57):26-36 
Yöntem: Kesitsel tipteki çalışmada, 20172018 akademik yılında tek bir tıp fakültesinde mezuniyet öncesi dönemde eğitim gören öğrencilere Batı ve arkadaşları tarafından geliştirilen, geçerli ve güvenilir bir ölçek olan "Hekimlik Mesleğine Yönelik Tutum Ölçeği (HMTÖ)" uygulanmıştır.

Veri analizi için SPSS 25.0 Paket programı (IBM Corp. Released 2011) kullanılmıştır. Tanımlayıcı istatistikler, Mann Whitney U ve Kruskal-Wallis testleri kullanılmıştır.

Bulgular: Araştırmaya öğrencilerin \%64.31'i $(n=564)$ katılmıştır. Ölçek ortanca değeri 93 bulunmuştur. Ölçeğin toplam puanı sınıflar arasında farklılık göstermemektedir. Ölçek alt boyutları olan "isteklilik, yardımcı olma ve mesleğe adanmışlık” da sınıflar arasında istatistiksel olarak anlamlı bir fark göstermemektedir.

Çalışma grubunun \%48.8'ini $(n=275)$ preklinik dönemde bulunan öğrenciler oluşturmaktadır. Preklinik ve klinik grupların ölçek toplam puanları karşılaştırıldığında, iki grup arasında istatistiksel olarak anlamlı bir fark görülmemiştir. Ölçeğin alt boyutlarının karşılaştırılmasında da her iki grubun tutumları arasında istatistiksel olarak anlamlı bir fark bulunmamıştır.

Sonuç: Çalışmanın yapıldığı tıp fakültesinde mezuniyet öncesi dönemde eğitim alan öğrencilerin hekimlik mesleğine yönelik tutumlarında, klinik öncesi ve sonrası yıllar arasında fark olmadığı saptanmıştır.

\section{ABSTRACT:}

Background: Attitude is said to be "a state of spiritual readiness that has a direct or dynamic effect on the individual's behavior towards all objects and situations to which he or she is concerned". Attitude is said to be an effective element in guiding the behavior of individuals and in their success. New knowledge and experiences change attitudes. It is important to measure the attitudes and make the necessary changes in order to change student behaviors in a positive way and increase their success. The aim of this study is to determine the attitudes of the medical students towards the medical profession and whether there is a difference between the preclinical and clinical periods.

Methods: In this cross-sectional study the "Attitude Scale for the Medical Profession (MPAS)”, a valid and reliable scale developed by Bati et al., was applied to undergraduate students studying in in a medical school during the 2017-2018 academic year. Descriptive statistics, Mann Whitney $U$ and Kruskal-Wallis tests were used.

Results: The overall participation rate was $64.31 \%(n=564)$. The median value of the scale was 93. The total score of the scale did not differ between classes. Likewise, subdimensions of the scale that are "willingness, help and commitment to the profession" did not show statistically significant difference between the classes. $48.8 \%(n=275)$ of the study group consisted of students in preclinical period. When the scale total scores of the preclinical and clinical groups were compared, no statistically significant difference was observed between the two groups. In the comparison of the sub-dimensions of the scale, no statistically significant difference was found between the attitudes of both groups.

Conclusion: Concerning the attitudes of medical students towards the medical profession, there were no differences across the preclinical and clinical phases.

\section{GíRiş}

Tutum, "yaşantı ve deneyimler sonucu oluşan, bireyin ilgili olduğu tüm nesne ve durumlara karşı davranışları üzerinde yönlendirici ya 
da dinamik bir etkiye sahip, ruhsal hazırlık durumu" olarak tanımlanmaktadır $(1,2)$. Bloom'un belirttiğine göre; tutum ve başarı arasındaki anlamlı korelasyon, tutumların en az bilişsel alan davranışları kadar önemli olduğunu göstermektedir (3). $\mathrm{Bu}$ nedenle eğitimciler tutumların ölçülüp değerlendirilmesi ile yakından ilgilenmektedir. Öğrencilerin konu, öğretmen ve okul gibi ögelere ilişkin tutumlarının eğitimde başarıyı önemli derecede etkileyen değişkenlerden olduğu ifade edilmektedir (3).

Bilimsel olarak incelemesi 19. yüzyılda başlayan tutum sözcüğü, Latince "harekete hazır" anlamına gelmektedir ve bireylerin davranışlarını yönlendiricidir (4). Tutum bireyseldir ve bireyin deneyimleri ve edindiği bilgilerin örgütlenmesi ile oluşmaktadır. Tutum, bireyin bir nesneye ilişkin düşünce, duygu ve davranışlarına bir bütünlük ve tutarlılık getirir (4). Araştırmacılar bireylerin tutumlarını öğrenmek için bireylerin düşünceleri, duyguları ve tepki eğilimleri ile ilgili bilgi edinmeye çalışır (4). Davranışların gözlenmesi bireylerin tutumlarına ilişkin önemli ipuçları verir. Ancak davranış gözlemlemek soyut cevaplar oluşturur. Tutumlar gizli veya varsayılan değişken olduklarından doğrudan ölçülemezler, bu nedenle tutumları değerlendirmek amacıyla bireylere düşünceleri, duyguları ve olaylara tepkileri ile ilgili bilgi sorulur. $\mathrm{Bu}$ bilgileri sorgulamak için geliştirilmiş farklı tutum ölçekleri oluşturulmuştur $(1,4)$.

Tüm dünyada sağlık profesyonelizmini değerlendirme amaçlı çok sayıda farklı araç geliştirilmiş ve uygulanmış olsa da yapılan bir sistematik derlemede çok azının metodolojik olarak uygun olduğu saptanmıştır (5). Söz konusu derlemede Hisar ve arkadaşlarının geliştirdiği "Hemşirelere Yönelik Profesyonellik Tutum Ölçeği” 74 ölçek arasından en güvenilir olarak saptanan üç araçtan birisi olmuştur (5, 6). Batı ve arkadaşları tarafından ise hekimlik mesleğine özgü "Hekimlik Mesleğine Yönelik Tutum Ölçeği” (HMTÖ) geliştirilmiştir (1). HMTÖ’nün, tıp fakültesi öğrencilerinin hekimlik mesleğine yönelik tutumlarının belirlenmesine, eğer varsa olumsuz tutumlara ilişkin iyileştirici çözümler üretilmesine, öğrenme ve öğretme sürecine ve literatüre katkıda bulunacağı düşünülmektedir.

Yeni bilgi ve deneyimler tutumların yavaş da olsa değişmesine sebep olur (4). Tıp fakültesi öğrencilerinin hekimlik mesleğine yönelik tutumlarının erken dönemde belirlenmesi, öğretim üyelerinin öğrencilere rol model olması ve tutumlarını olumlu yönde etkilemesi açısından önem taşımaktadır. Belirlenen tutumların gerekli olan durumlarda değişmesine yönelik adımların atılması hekimlik mesleğini geliştirir. Ayrıca sağlık hizmetlerinin uygulanması ile ilgili yasa ve düzenlemelerin mesleğe yönelik tutumlar üzerindeki etkisi göz ardı edilmemeli, etik ve profesyonel değerler konusunda duyarlılığın dinamik tutulması sağlanmalıdır.

Uluslararası literatürde yapılan taramalarda tıp fakültesi öğrencilerinin tutumlarının sıkça araştırılan bir konu olduğu dikkat çekmiştir. Örneğin tıp fakültesi öğrencilerinin iletişim becerilerini öğrenmeye yönelik tutumları, web tabanlı asenkron sağlık meslek kursuna yönelik tutumları, psikiyatriye yönelik tutumları, hastalıkların psikososyal boyutlarına ilişkin tutumları incelenen konular arasındadır (7-11).

Arkar ve Eker'in yaptıkları bir çalışmada, psikiyatri stajının tutumlar üzerinde bir değişiklik yaratmadığı, ancak bu konuda bir anket uygulanmasının ve konunun gündeme getirilmesinin daha olumlu düşünce ya da tutumlara neden olduğu bildirilmektedir. Yazarlar, hastalarla etkileşimi içeren uygulamalı psikiyatri stajının önemli bir değişime yol 
açmamasının bir nedeni olarak, öğrencilerin zaten hekimliği seçen bir kesim olduğundan tutumlarının optimum olabileceği ve daha fazla değişmesinin olanaklı olmayabileceğini ileri sürmüşlerdir (12).

Griffith ve Wilson, öğrencilerin klinik rotasyonlar sürecinde farklı hasta tipleri ve mesleğe yönelik tutumlarını belirlemeye çalışmışlardır (13). Üçüncü sınıf öğrencilerini 16 haftalık cerrahi staj eğitiminin başında ve sonunda bir ölçme aracıyla değerlendirmişlerdir. Bulgular, staj eğitiminin sonunda üçüncü sınıf öğrencilerinin kronik ağrıları olan yaşı hastalara karşı daha az idealist davrandıklarını, mesleğe yönelik idealist tutumlarının da azaldığını göstermektedir (13).

Klinik öncesi dönemde teorik ders yükü ağırlıklı bir ders programı ile eğitim gören öğrencilerin hasta, hasta yakınları ve birlikte çalışacakları meslektaşlarıyla birlikte, ağırlıklı olarak uygulamalı bir eğitim programına geçişleri hekimlik mesleğine yönelik tutumlarında değişiklik yaratabilmektedir. Yapılan çalışmalar eğitim yılı artışı ile öğrencilerde olumsuz tutum ve kinisizm olduğunu göstermektedir (14). Tutum değişikliğinin yönü HMTÖ ile belirlenebilir. $\mathrm{Bu}$ çalışma, farklı sınıflardaki öğrencilerin hekimlik mesleğine yönelik tutumların belirlenmesine, varsa olumsuz tutumlara ilişkin iyileştirici çözümler üretilmesi konusunun görüşülmesine olanak sağlayacaktır. Çalışmanın öğrenme ve öğretme sürecine ve literatüre katkıda bulunacağı düşünülmektedir.

$\mathrm{Bu}$ çalışmanın amacı, tıp fakültesinde eğitim gören öğrencilerin hekimlik mesleğine yönelik tutumlarının ve tıp öğrencilerinin klinik öncesi ve klinik dönemde hekimlik mesleğine yönelik tutumları arasında siniflar arası fark olup olmadığının belirlenmesidir.

\section{YÖNTEM}

Kesitsel tipteki bu çalışmada, bir tıp fakültesindeki mezuniyet öncesi öğrencilere "Hekimlik Mesleğine Yönelik Tutum Ölçeği (HMTÖ)" uygulanmıştır. Çalışma evrenini 2017-2018 akademik y1lında eğitim gören tüm öğrenciler (1 - 6. sınıflar) oluşturmuştur. Tüm öğrencilere 2018 Mart - Haziran aylarında basılı ölçek ulaştırılmış ve veri toplanmıştır.

Araştırma, İzmir Katip Çelebi Üniversitesi (İKÇÜ) Sosyal Araştırmalar Etik Kurulu tarafindan 03/04/2018 tarih 2018/05 toplantısında 06 karar numarası ile onaylanmıştır.

\section{Hekimlik Mesleğine Yönelik Tutum Ölçeği (HMTÖ):}

Araştırmada veri toplamak için kullanılmış olan araçtır. HMTÖ, 2006 yılında Batı ve arkadaşları tarafından geliştirilmiş ve geçerlilik ve güvenilirliği test edilmiştir (1). Ölçek beşli Likert tipinde 12 olumlu ve 12 olumsuz olmak üzere toplam 24 madde ve üç alt boyuttan oluşmaktadır. Verilen cevaplar 'hiç katılmıyorum'dan 'tamamen katılıyorum'a kadar değişmektedir. Ölçeğin ilk alt boyutundaki 15 madde "isteklilik", ikinci alt boyutundaki beş madde "yardımcı olma" ve üçüncü alt boyutundaki dört madde de "mesleğe adanmışlık" olarak adlandırılmaktadır.

Alınabilecek toplam en yüksek puan 120, en düşük puan ise 24'tür. "İsteklilik" alt boyutunda alınabilecek en yüksek puan 75 iken "yardımcı olma" ve "mesleğe adanmışlık" alt boyutlarında alınabilecek en yüksek puanlar sırasıyla 25 ve 20 'dir. Ölçeğin tamamından veya alt boyutlardan alınan puanların yüksek olması olumlu tutumu, düşük olması olumsuz tutumu göstermektedir(15).

\section{Preklinik ve klinik dönemin tanımlanması:}

Araştırmanın yürütüldügü tıp fakültesinde 1. ve 2. sınıf öğrencileri hastane binasından ayrı merkez eğitim kampüsünde eğitim 
görmektedirler. $\mathrm{Bu}$ dönemde "tıp bilimleri" ile "klinik bilimlere giriş" ve "mesleki beceri uygulama" ders grupları yürütülmektedir (16). Öğrenciler henüz gerçek hastalar ve hastane ortamı ile temas etmediğinden bu dönem çalışmamızda "preklinik dönem" olarak tanımlanmıştır.

Öğrenciler 3. sınıftan itibaren eğitimlerini ilgili yönetmelik kapsamında imzalanan "Birlikte Kullanım Protokolü” çerçevesinde eğitim ve hizmetlerin birlikte yürütüldüğü Sağlık Bakanlığı'na bağlı bir eğitim ve araştırma hastanesinde sürdürmektedir (17). Üçüncü sınıf öğrencileri "temel bilimler" "klinik bilimlere giriş" ile "iyi hekimlik uygulamaları" ve "klinik beceri” ders grubu eğitimlerini almaktadırlar. Dördüncü ve 5. sınıfta dahili ve cerrahi tıp bilimleri staj derslerini tamamlayan öğrenciler, 6. sinıfta hastanede ve saha uygulama birimlerinde (Eğitim Aile Sağlığ Merkezi ve İlçe Sağlık Müdürlüğü) "intörn doktor" olarak görev yapmaktadırlar (16). Bu gruptaki öğrenciler gerçek bir hastane ortamı ve hastalar ile yoğun şekilde karşılaşmış olduklarından bu dönem çalışmamızda "klinik dönem” olarak tanımlanmıştır.

\section{Veri analizi :}

Veri tabanı oluşturulduktan sonra her öğrenci için toplam puan ve alt boyut puanları hesaplanmıştır.

Tanımlayıcı istatistikler sayı ve yüzde ile verilmiştir. Bağımsız değişkenler arasındaki karşılaştırmalarda -değişkenler normal dağılım göstermediğinden- Mann Whitney $U$ ve Kruskal-Wallis testleri kullanılmıştır. Sonuçlar ortanca (medyan) değerler ve çeyreklikler arası aralık (\%25-\%75) ile gösterilmiş, "p" değerinin 0.05 'ten küçük olması istatistiksel anlamlılık olarak kabul edilmiştir. Veri analizi için SPSS 25.0 Paket programı (IBM Corp. Released 2011) kullanılmıştır.

Ölçeğin iç tutarlılı̆̆ kontrol edilmiş olup preklinik grup ve klinik dönemdeki gruplar ve çalışma grubunun tümü için ayrı ayrı hesaplanmış ve Cronbach Alpha katsayısı 0.95 olarak bulunmuştur.

\section{BULGULAR}

Çalışmanın yürütüldüğü fakültede 2017-2018 eğitim öğretim yılında 877 öğrenci kayıtlıydı. Toplam 567 öğrenci çalışmaya katılmayı kabul etmiştir. Toplanan ölçeklerden üç tanesi eksik doldurulmuş olduğundan geçersiz kabul edilerek çalışma dışında bırakılmıştır. Sonuçta öğrencilerin \%64.31'inin (n:564) yanıtları analiz edilmiştir. Sınıf düzeylerine göre öğrencilerin araştırmaya katılım oranları tablo 1 'de verilmiştir.

Tablo 1: Ölçek Sayılarının Sınıflara Göre Dağılımı

\begin{tabular}{lccc}
\hline Sinıf düzeyi & $\begin{array}{c}\text { Toplam öğrenci } \\
\text { Sayısı }(N)\end{array}$ & $\begin{array}{c}\text { Geçerli ölçek } \\
\text { sayıs1 }(n)\end{array}$ & $\begin{array}{c}\text { Geçerli ölçek } \\
\text { oranı }(\%)\end{array}$ \\
\hline 1. sınıf & 195 & 139 & 71.28 \\
2. sinıf & 151 & 136 & 90.07 \\
3. sinıf & 160 & 116 & 72.50 \\
4. sinıf & 155 & 84 & 54.19 \\
5. sinıf & 121 & 66 & 54.55 \\
6. sinıf & 95 & 23 & 24.21 \\
Toplam & $\mathbf{8 7 7}$ & $\mathbf{5 6 4}$ & $\mathbf{6 4 . 3 1}$ \\
\hline
\end{tabular}


Araştırmaya katılan tüm öğrenci yanıtları $(n=564)$ incelendiğinde, ölçek ortanca değeri 120 tam puan üzerinden 93 (25p.-75p.; 81 104) olarak bulunmuştur. Ölçeğin toplam puanı sınıflar arasında farklılık göstermemektedir $(p=0.371)$. Tüm katılımcılar için alt boyutlar ayrı ayrı analiz edildiğinde; “isteklilik" alt boyutu ortanca değeri 75 tam puan üzerinden 60 (25p.-75p.; 52 - 68), "yardımcı olma" alt boyutu ortanca değeri 25 tam puan üzerinden 20 (25p.-75p.; 18 - 23) ve "mesleğe adanmışlik" alt boyutu ortanca değeri 20 tam puan üzerinden 13 (25p.-75p.; 10 - 15) olarak hesaplanmıştır. İsteklilik $(\mathrm{p}=0.197)$, yardımc1 olma $(\mathrm{p}=0.347)$ ve mesleğe adanmışl1k $(p=0.208)$ alt boyutları da siniflar arasında istatistiksel olarak anlamlı bir fark göstermemektedir.

Ölçek toplam puan ve alt boyutlarının sınıf düzeyine göre ayrı ayrı ortanca değerleri tablo 2 'te gösterilmektedir.

Tablo 2: Sınıf Düzeyine Göre Ölçek Toplam Puan ve Alt Boyut Ortanca Değerleri

\begin{tabular}{ccccc}
$\begin{array}{c}\text { Sinıf } \\
\text { düzeyi }\end{array}$ & $\begin{array}{c}\text { Toplam puan } \\
\text { Ortanca } \\
(25 p .-75 p .)\end{array}$ & $\begin{array}{c}\text { İsteklilik } \\
\text { ortanca } \\
(25 p .-75 p .)\end{array}$ & $\begin{array}{c}\text { Yardımcı olma } \\
\text { ortanca } \\
(25 p .-75 p .)\end{array}$ & $\begin{array}{c}\text { Mesleğe adanmışlik } \\
\text { ortanca } \\
(25 p .-75 p .)\end{array}$ \\
\hline 1. sinıf & $96(83-105)$ & $63(55-68)$ & $21(19-24)$ & $13(9-15)$ \\
2. sinıf & $93(82-103)$ & $59(51-69)$ & $20(18-23)$ & $13(11-15)$ \\
3. sinıf & $90(78-103)$ & $59(50-67)$ & $20(17-23)$ & $13(11-16)$ \\
4. sinıf & $90(78-105)$ & $59(51-67)$ & $20(17-23)$ & $13(10-15)$ \\
5. sinıf & $92(80-104)$ & $60(53-68)$ & $21(20-24)$ & $13(9-15)$ \\
6. sinıf & $96(89-109)$ & $65(57-70)$ & $21(19-24)$ & $13(12-15)$ \\
\hline
\end{tabular}

Çalışma grubunun \%48.8'ini $\quad(n=275)$ her iki grubun tutumları arasında istatistiksel preklinik dönemde bulunan öğrenciler olarak anlamlı bir fark bulunmamıştır $(\mathrm{p}>0.05)$. oluşturmaktadır. Prelinik ile klinik dönemde Öğrencilerin genel olarak "hekimlik mesleğine eğitim gören öğrencilerin ölçek toplam puanları yönelik tutumları" ve ayrıca "isteklilik, yardımcı karşılaştırıldığında, iki grup arasında istatistiksel olma ve mesleğe adanmışlık” tutumları olarak anlamlı bir fark görülmemiştir $(\mathrm{p}=0.203)$. klinik öncesi ve klinik dönemde benzerlik Ölçeğin alt boyutlarının karşılaştırılmasında da göstermektedir (tablo 3).

Tablo 3 : Preklinik ve Klinik Dönem Öğrencilerinin Ölçek Toplam Puan ve Alt Boyut Puanlarının Karşılaştırılması

\begin{tabular}{lccc}
\hline & $\begin{array}{c}\text { Preklinik dönem }(n=275) \\
\text { ortanca }(25 p-75 p .)\end{array}$ & $\begin{array}{c}\text { Klinik dönem }(n=289) \\
\text { ortanca }(25 p .-75 p .)\end{array}$ & $p$ \\
\hline $\begin{array}{l}\text { Ölçek toplam puanı } \\
\text { Ölçek alt boyut puanları }\end{array}$ & $94(83-104)$ & $92(79-104)$ & 0.203 \\
İsteklilik & $60(54-68)$ & $59(51-67)$ & 0.124 \\
Yardımcı olma & $21(19-23)$ & $20(18-24)$ & 0.429 \\
Mesleğe adanmışlık & $13(10-15)$ & $13(10-15)$ & 0.976 \\
\hline
\end{tabular}




\section{TARTIŞMA}

Araştırmamızın yanıt oranı \%64.31'di. Anket türü çalışmaların geçerliliği için literatürde belli bir asgari standart olmamasına rağmen, $\% 60$ 'ın üzeri yanıt oranının hedeflenmesini öneren kaynaklara göre yeterli sayıda öğrenciye ulaşı1dığı düşünülmektedir (18).

Araştırmada tüm öğrencilere ait ölçek toplam puan ortanca değeri olan 93 , başka bir tıp fakültesinde aynı ölçek kullanılarak yapılan güncel bir çalışmada 92 olarak bulunan puanla benzerlik göstermektedir (19). Çalışmamızda ölçeğin en yüksek toplam puanı 1. ve 6. sinıf ve en düşük puanı 3. ve 4. sınıf öğrencileri almıştır. Sinıflar arasındaki bu fark istatistiksel olarak anlamlı değildir. Çalışmamızın sonuçlarından farklı olarak, Türkiye'de altı farklı tıp fakültesinde, 1. ve 6. sinıf öğrencilerinin hekimlik mesleğine yönelik tutumlarının yine HMTÖ kullanılarak karşılaştırıldığı bir çalışmada, 1. sınıf öğrencilerin ölçek toplam ve alt boyut puanlarının 6. siniflara göre anlamlı olarak daha yüksek olduğu saptanmıştır (15). Diğer bir tıp fakültesi son sınıf öğrencilerinde yapılan çalışmada öğrencilerin yarıdan fazlasının hekimlik mesleği hakkındaki görüşlerinin tıp eğitimi boyunca olumsuz yönde değiştiği gösterilmiştir (20). Tip fakültesinden mezun olan öğrencilerin, tıp fakültesine girdikleri zamandan daha az idealist, daha az yardımsever ve daha az insancıl olduğunu öne süren başka araştırmalar vardır (21). Bu çalışmada 6. Sınıf öğrencilerine ulaşım diğer sınıflara göre daha azdır, öğrencilerin tümüne ulaşım sağlanması durumunda benzer olumsuz sonuç görülebilirdi. Bizim çalışmamız da dahil yayınlanmış olan çalışmalar tanımlayıcı veya kesitsel tipte çalışmalar olup, öğrencileri tüm eğitim hayatları boyunca takip etmemiştir. Tıp fakültelerinin uzun ve yorucu eğitim sürecinde bazı öğrencilerin tutumları olumlu, bazılarının da olumsuz yönde değişkenlik gösterebilir.

İsteklilik, yardımcı olma ve mesleğe adanmışlık ölçek alt boyut puanları sinıflar arasında istatistiksel olarak farkl1lık göstermemektedir (Tablo 3). Bizim çalışmamızdan farklı olarak bir çalışmada ölçeğin her üç alt boyut puanları 1.sınıf öğrencilerinde 3. Sınıf öğrencilerine göre anlamlı olarak yüksek bulunmuştur (15).

Çalışmamızda İsteklilik alt boyut ortanca puanları 60 olarak bulunmuş ve sınıflar arasında anlamlı farklılık saptanmamıştır. Çalışmamızın yürütüldüğü fakültede yapılan başka bir çalışmanın sonuçlarına göre öğrencilerin $\% 93,5$ 'u tıbba ilgi duyarak, \%91,3'ü tıp eğitimini kişiliğine uygun bulduğu için mesleği tercih etmiştir (22). Bu öğrencilerin mesleği isteyerek seçmiş olmaları isteklilik alt boyut puanı ile ilişkili olduğu şeklinde yorumlanabilir. Çalışmamızda Yardımcı olma alt boyut ortanca puanları 20 olarak bulunmuş ve sınıflar arasında anlamlı farklılık saptanmamıştır. Öğrencilerin hata yapma kaygıları anksiyetelerini arttırmakta ve yardımcı olma davranışlarını engelleyici bir faktör olarak düşünülmektedir. Yapılan bir çalışmada iki farklı tıp fakültesi öğrencilerinin anksiyete düzeyleri araştırılmıştır. Eğitim programı içeriğindeki farkl1lıklar anksiyete düzeyleri ile ilişkili bulunmuştur. Preklinik dönemde eğitim almış olan öğrencilerin klinik dönemde anksiyete düzeyleri daha düşük bulunmuştur (23). Klinik dönemin başındaki öğrenciler hata yapmaktan ve hastalara ve deneyimli meslektaşlarına karşı mahcup olmamak için yardımcı olma isteklerini bastırabilirler (24). Eğitim programının öğrencilerin gereksinimlerine yönelik düzenlenmesi bu durumu önleyici olacağ 1 düşünülmektedir (25). Fakültemiz eğitim programında preklinik dönemden itibaren öğrencilerin meslek yaşamında gereksinim duyabilecekleri bilgi, beceri ve tutuma yönelik 
dersler ve etkinlikler yer almaktadır. Yardımcı olma alt boyut puanının aynı olarak sürmesinin sebebi bu olabilir.

Çalışmamızda Mesleğe adanmışlık alt boyut ortanca puanları 13 olarak bulunmuş ve sınıflar arasında anlamlı farklılık saptanmamıştır. Yeni tıp eğitimi modellerinde öğrencilerin pasif konumdan aktif hale geçmeleri ve program geliştirme aşamalarında etkin rol almaları önerilmektedir. $\mathrm{Bu}$ sayede sistemin bir parçası olmaları sağlanmaktadır (25). Fakültemizde eğitim programı geliştirme ve değerlendirme çalışmalarına öğrencilerin katılımı önemsenmekte ve sağlanmakta böylece onların mesleğin içinde, adanmışlık tutumuyla eğitimlerini sürdürmeleri sağlanmaktadır. Mesleğin benimsenmesinde şüphesiz eğiticilerin rol model olarak davranışları çok etkilidir. Birinci sınıftan altıncı sınıfa kadar mesleğe adanmışlık alt boyut puanının aynı kalması olumlu bir durum olarak yorumlanmaktadır.

Tıp fakültesi eğitim süreci uzun ve zorlu bir yol olup öğrencilerin birçok farklı deneyim yaşamasına neden olmaktadır. Preklinik dönemde öğrenciler yoğun teorik dersler, sınav kaygısı ve henüz hasta ile karşılaşmamanın yarattığı hayal kırıklığı ile olumsuz yönde tutum geliştirebileceği gibi, yine zorlu bir sınav süreci sonrası tıp fakültesine girmeye hak kazanmış olma ve hekim olacak olma heyecanıyla olumlu yönde tutum da gösterebilir. Tıp eğitimindeki en önemli yol ayrımlarından biri, öğrencilerin gerçek klinik ortamla karşılaştıkları dönem olmaktadır. $\mathrm{Bu}$ dönemde öğrenciler yoğun ve zorlu hastane çalışma koşulları, nöbetler, tıp eğitiminin kendisinin yaratmış olduğu stres faktörleri, mezuniyet sonrası kariyer tercih kaygısı gibi nedenlerle tükenmişlik, bıkkınlık hissedebilir veya tam tersi hastalara yardımcı olabilme, itibarlı ve iş garantili bir meslek sahibi olacak olma duygusuyla mesleki doyum ve mutluluk da yaşayabilir $(22,23,26,27)$. Tüm bu farklı yaşantı ve deneyimlerin eğitim süreci boyunca hekimlik mesleğine yönelik tutuma olumlu veya olumsuz yansımalarının olması olasıdır. Örneğin farklı bir üniversitede HMTÖ kullanılarak mezuniyet öncesi öğrenciler ve araştırma görevlileri ile yürütülen bir çalışmada mezuniyet öncesi öğrencilerin puanlarının araştırma görevlilerinden daha yüksek olduğu, mezuniyet öncesi ögrrencilerinde ise 6 . sinıfta en düşük olduğu bulunmuştur (19). Araştırma görevlisi hekimlerdeki puanın daha düşük olmasının nedeni, "artan sorumluluklar, iş yükü, günlük çalışma saatlerinin ve nöbet sayısının fazlalığı, sürekli hasta ve acı çeken insanlarla karşılaşmak, performans endişesi, hasta ve hasta yakınları tarafından duygusal ve sözel şiddete maruz kalma" gibi faktörler olarak yorumlanmış, bulunduğu bölümde iki yıldan daha fazla çalışan hekimlerde ölçek puanının daha yüksek olduğu vurgulanmıştır (19). Söz konusu çalışmadaki bu veriler, mezuniyet öncesinde öğrencilerin yeterli deneyim ve iletişim becerisi kazanmasının önemini göstermektedir. T1p eğitimi boyunca hekim adaylarının bol deneyim kazanması, mezuniyet sonrası yeni hekimlerin kaygısını önemli ölçüde azaltacaktır. Kaygının azalması, genç hekimlerin özgüvenini ve dolayısı ile mesleğe yönelik tutumlarını da olumlu yönde etkileyecektir.

Çalışmamızda sosyodemografik değişkenler sorgulanmamıştır. Bir araştırmada "cinsiyet, mesleği tercih sırası, mesleği seçmekten dolayı duyulan memnuniyet, meslekte çalışmaya başlama durumu, çalışma yılı ve devam edilen sınıf” değişkenleri hekimlik mesleğine yönelik tutumu etkileyen faktörler olarak bulunmuştur (19). Köksal ve arkadaşları tarafından Cerrahpaşa Tıp Fakültesi öğrencilerinin tıp eğitimi ve mezuniyet sonrası ile ilgili tutumlarının incelendiği çalışmada, öğrencilerin 
yaklaşık \% 40'ının ilk üç tercihlerinde tıp fakültesinin yer almamış olduğu görülmektedir. $\mathrm{Bu}$ oran mesleği isteyerek seçmedikleri yönünde yorumlanmıştır (28).

Sosyodemografik veriler değiştirilmesi mümkün olmayan faktörler olup ancak istemeden tıp mesleği tercihi nedeniyle ortaya çıkan olumsuz tutum zamanında ve uygun tercih danışmanlığ ile önlenebilir. Tıp eğitimine başlamış ve bu mesleği sürdürmek isteyen hekim adaylarının ise sürekli gözlemlenerek eğitim süreçlerini en verimli şekilde tamamlamalarının sağlanması tutumlarını hem mezuniyet öncesi, hem de mezuniyet sonrasinda olumlu yönde etkileyecektir. Bizim çalışmamızda preklinik ile klinik dönemde eğitim gören öğrencilerin ölçek toplam puanları ve alt boyut puanları arasında anlamlı fark görülmemiştir. Benzer çalışmalarda sunulan sonuçlardan farklı olarak saptamış olduğumuz tutum düzeyindeki istikrarlı bu sonuç, araştırmanın yapıldığı tıp fakültesine giren öğrencilerin hem meslek seçimlerini sağlıklı yaptıklarını, hem de eğitim süreci boyunca motivasyonlarının sabit düzeyde kaldığını düşündürmektedir.

Çalışmamızın farklı özelliklerinden biri, afiliye bir tıp fakültesinde yürütülmüş olmasıdır. Birlikte kullanım protokolü kapsamında eğitim gören tıp öğrencilerinin memnuniyet düzeylerini inceleyen bir çalışmada, öğrencilerin genel anlamda eğitimden, eğitimcilerden memnun olduğu, ancak sosyal aktivite, öğrenci kulübü gibi imkanları az bulduğu belirtilmiştir. Bu durum, fakülte binasının üniversite kampüsünden uzak olması ile ilişkilendirilmiştir (29). Çalışmamızın yürütülmüş olduğu tıp fakültesinde öğrenciler ilk iki yıl eğitimlerini sosyal imkanların bolca bulunduğu merkezi üniversite kampüsünde geçirmektedirler. Bu süreçte aidiyet duygusunun gelişmesi ve sosyal etkileşimler, öğrencilerin memnuniyetini, dolayısıyla genel anlamda almış oldukları eğitime yönelik tutumu olumlu yönde etkilemiş olabilir.

\section{Kisıtlılıklar}

Bu çalışma sadece tek bir tıp fakültesi öğrencileri arasında yapılmıştır. Çalışmada en yüksek yanıt oranı ilk iki sınıfta, en düşük yanıt oranı 6. sınıf öğrencilerde olmuştur. Daha büyük sınıflardan daha az sayıda veri toplanması durumu, başka çalışmalarla benzerlik göstermektedir (15). Ayrıca öğrencilerin tutumlarını etkileme ihtimali bulunan sosyodemografik değişenlere ilişkin bilgiler sorgulanmamıştır.

Ölçeğe verecekleri yanıtları etkilememesi açısından, birlikte kullanım protokolü ile ilgili ayrıca soru sorulmamış, bu değişkenin mesleğe yönelik tutuma etkisi sürecin kendisi ile birlikte ele alınarak yorumlanmıştır. Bu nedenle birlikte kullanım protokolünün getirdiği fayda veya zararlar, bu çalışmanın sonuçları ile tek başına değerlendirilmemelidir.

\section{SONUÇ}

$\mathrm{Bu}$ çalışmada bir tıp fakültesinde eğitim gören 1.- 6. sınıf öğrencilerin hekimlik mesleğine yönelik tutumları HMTÖ yardımıyla belirlenmiş ve farklı sınıf düzelerine göre karşılaştırılmıştır. Kliniköncesi ile klinik dönem karşılaştırıldığında iki grup arasında hekimlik mesleğine yönelik tutumlarında bir fark olmadığı görülmüştür. Bu durum çalışmanın yürütüldüğü tıp fakültesinde öğrencilerin tutumlarında bir değişiklik olmadığı ve öğrencilerin motivasyonlarının sabit kaldığı şeklinde yorumlanabilir. Tüm eğitim sürecinde olumlu veya olumsuz tutum gelişimine etki eden faktörlerin daha iyi anlaşılabilmesi uzunlamasına çalışmalarla mümkün olacaktır.

Araştırma, birlikte kullanım protokolü kapsamında eğitimini sürdüren bir tıp fakültesinde ögrencilerin preklinik ve klinik dönemdeki mesleğe yönelik tutumlarını 
inceleyen bir çalışmadır. Ülkemizde sayısı artan bu tıp fakültesi modelinin ve eğitim sürecindeki yaşantının hekimlik tutumlarına etkisinin daha iyi anlaşılması için benzer çalışmaların geliştirilerek tekrarlanması, gelecekteki tıp eğitiminin şekillendirilebilmesi, hekim adaylarının mesleğe yönelik tutumlarının daha da iyileştirilmesi için önemli ipuçları sağlayacaktır.

\section{KAYNAKLAR}

1. Batı AH, Bümen NT. Hekimlik mesleğine yönelik tutum ölçeğinin geliştirilmesi. Tip Eğitimi Dünyası. 2006;(23):41-50.

2. Özkal N. Sosyal Bilgiler Dersine Yönelik Tutum Ölçeğinin Geliştirilmesi. Eğitim ve Bilim. 2002;27(124):52-55.

3. Bloom SB. Human Characterlstles and School Learnlng. McGraw-Hill Book Company. New York: McGraw-Hill Book Company; 1976.

4. Tavşancıl E. Tutumların Ölçülmesi ve SPSS ile Veri Analizi. Nobel Akademik Yayıncılık; 2019.

\section{LiH, Ding N, Zhang Y, Liu Y, Wen D. Assessing} medical professionalism: A systematic review of instruments and their measurement properties. PLoS One. 2017;12(5):e0177321.

6. Hisar F, Karadağ A, Kan A. Development of an instrument to measure professional attitudes in nursing students in Turkey. Nurse Educ Today. 2010;30(8):726-30.

7. Rees C, Sheard C, Davies S. The development of a scale to measure medical students' attitudes towards communication skills learning: the
Communication Skills Attitude Scale (CSAS). Med Educ. 2002;36(2):141-7.

8. Shankar R, Dubey A, Mishra P, Deshpande V, Chandrasekhar T, Shivananda P. Student attitudes towards communication skills training in a medical college in Western Nepal. Educ Heal Chang Learn Pract. 2006;19(1):71-84.

9. Lesh SG,|Guffey JS, Rampp LC. Changes in Student Attitudes Regarding a Web-Based Health Profession Course. 2000; Available from: https://eric.ed.gov/?id=ED441386

10. Wilkinson DG, Greer S, Toone BK. Medical students' attitudes to psychiatry. Psychol Med. 1983;13(1):185-92.

11. Dornbush RL, Singer P, Brownstein EJ, Freedman AM. Maintenance of psychosocial attitudes in medical students. Soc Sci Med. 1985;20(1):107-9.

12. Gürlek Yüksel E, Taşkın EO. Türkiye'de hekimler ve tıp fakültesi öğrencilerinin ruhsal hastalıklara yönelik tutum ve bilgileri. Anadolu Psikiyatr Derg. 2005;6:113-21.

13. Griffith $\mathrm{CH}$, Wilson JF. The loss of student idealism in the 3rd-year clinical clerkships. Eval Health Prof. 2001;24(1):61-71.

14. Testerman JK, Morton KR, Loo LK, Worthley JS, Lamberton HH. The Natural History of Cynicism in Physicians. Academic Medicine. 1996;71:43-45.

15. Bati AH, Sarikaya O, Senol Y, Ertem M, Caliskan D, Buyukakkus A. How do medical students perceive professional attitudes? A multicenter study. Kuwait Med J. 2010;42(2):112-7. 
16. İzmir Katip Çelebi Üniversitesi Tıp Fakültesi - 2017-2018 Ders Program1. 2017; Available from: http://tip.ikc.edu.tr/S/15910/2017-2018

17. Sağlık Bakanlığı ve Bağlı Kuruluşlarına Ait Kurum ve Kuruluşlar ile Devlet Üniversitelerinin İlgili Birimlerinin Birlikte Kullanımı ile İşbirliği Usul ve Esasları Hakkında Yönetmelik. Sağlık Bakanlığı; 2017. Available from: http://www.resmigazete.gov.tr/ eskiler/2017/06/20170616-2.htm

18. Fincham JE. Response rates and responsiveness for surveys, standards, and the Journal. Am J Pharm Educ. 2008;72(2):43.

19. Aydoğan S, Çalışkan Pala S, Işıklı B Mezuniyet Öncesi ve Sonrasinda Hekimlik Mesleğine Yönelik Tutum. Ankara Med J. 2019;19(1):10-20.

20. Yaşar AB, Özdemir B, Kılıçtaş Ç ve ark. Kocaeli Üniversitesi Tip Fakültesi son sinıf öğrencilerinin eğitimlerini değerlendirmesi. 2013; Available from: http://tip.kocaeli. edu.tr/docs/raporlar_sunumlar/tip_egitimi arastirmasi2013.pdf

21. Crandall SJS, Volk RJ, Cacy D. A Longitudinal Investigation of Medical Student Attitudes Toward the Medically Indigent. Teach Learn Med. 1997;9(4):254-60.

22. Can H, Gök Balcı U, Öngel K. İzmir Katip Çelebi Üniversitesi Tip Fakültesi birinci sınıf öğrencilerinin meslek seçiminde etkili faktörler. Eurasian J Fam Med. 2013;2(2):77-82.

23. Sarikaya O, Civaner M, Kalaca S. The anxieties of medical students related to clinical training. Int J Clin Pract 2006; 60:1414-1418.
24. Radcliffe C, Lester H. Perceived stress during undergraduate medical training: a qualitative study. Med Educ 2003; 37: 32-8.

25. Harden RM. Ten key features of the future medical school-not an impossible dream. Medical Teacher. 2018; 1-5. https://doi.org/10 $.1080 / 0142159 X .2018 .1498613$.

26. Fares J, Al Tabosh H, Saadeddin Z, El Mouhayyar C, Aridi H. Stress, burnout and coping strategies in preclinical medical students. N Am J Med Sci. 2016;8(2):75.

27. Yalçınoğlu N, Kayı İ, Işıı Ş, Aydın T, Zengin Ş, Karabey S. İstanbul Üniversitesi İstanbul Tip Fakültesi son sınıf öğrencilerinin tıp eğitimi ile ilgili görüşleri. İstanbul Tip Fakültesi Derg. 2013;75(3):41-5.

28. Köksal S, Vehid S, Tunçkale A, Çerçel A, Erginöz E, Kaypmaz A, ve ark. Cerrahpaşa tıp fakültesi ögrencilerinin tıp eğitimi ve mezuniyet sonrası ile ilgili tutumları. Cerrahpaşa Tıp Derg. 1999;30(4):251-8.

29. Bilir F, Köse E, Kaçal Z. Afiliasyon Kapsamında Eğitim Gören Tıp Öğrencilerinin Memnuniyet Düzeyleri ve İlişkili Faktörlerin İncelenmesi. J Hum Rhythm. 2018;4(1):59-66. 